\title{
Gambling in Transition: Assessing Youth Narratives of Gambling in Nigeria
}

- Tunde Adebisi,

- Oluwatobi Alabi,

- Ogadimma Arisukwu \&

- Festus Asamu

Journal of Gambling Studies (2020)

\section{Abstract}

Nigeria has witnessed some significant changes in gambling which have resulted in more people becoming interested in the activity. In an attempt to increase participation, bookmakers have introduced a variety of innovations. Literature has established that this increased participation is intergenerational, cross-cultural, and inter-religious. Particularly among Nigerian youth, participation in gambling cuts across all age groups, socioeconomic status, and gender. Both financial and social rewards have been identified as reasons why many youths gamble. Through a qualitative lens, this study investigates how the dynamics of gambling in recent times have affected the biographies of youth within a relatively deprived socio-economic locality in Kwara State, Nigeria. Thirty young gamblers between the ages of 15 and 29 were engaged in a semi-structured interview session. Drawing from the meaning of 'youth' from a sociological lexicon, one can advance this unique narrative of the transitions in gambling activities which can occur as a result of the youths' biographies and socio-economic status. Nigerian youth adopt three specific gambling types as a coping strategy in the face of a crisisridden socio-economic structure characterised by poverty, and unemployment. As such, gambling has become a normative activity experimented by the youth to survive the harsh economic conditions. This study therefore argues the need to situate the discourse of youth gambling within the social, cultural, and economic context in which they are located in Nigeria. In addition, the authors provide a framework for understanding the complexity of youth gambling in Nigeria.

Read Full Text Online at: https://rdcu.be/b7SDq 


\section{References}

1. Abdulai, A., \& Inkoom, A. (2016). Guidance and counselling in early childhood teacher training. American Journal of Educational Research, 4(7), 531-538.

\section{Google Scholar}

2. Abdi, T. A., Ruiter, R. A. C., \& Adal, T. A. (2015). Personal, social and environmental risk factors of problematic gambling among high school adolescents in addis ababa ethiopia. Journal of Gambling Studies, 31(1), 59-72. https://doi.org/10.1007/s10899-013-9410-9.

\section{Article PubMed Google Scholar}

3. Abubakar, A., Audu, P. M., \& Aisha, H. S. (2017). Mathematical Modeling for Population Projection and Management A Case Study Of Niger State, 13(5), 51-57. https://doi.org/10.9790/57281305035157 .

\section{Article Google Scholar}

4. Adejimola, A. S., \& Olufunmilayo, T. (2009). Spinning off an entrepreneurship culture among Nigerian University Students: Prospects and challenges. African Journal of Business Management, 3(3), o80-088.

\section{Google Scholar}

5. Adenugba, A., \& Akhuetie, R. (2018). Knowlege and perception of gambling among Youths In Ibadan. Oyo State Nigeria: North Local Government.

\section{Google Scholar}

6. Aguocha, C. M., Duru, C. B., Nwefoh, E. C., Amadi, K. U., Olose, E. O., Igwe, M. N., et al. (2019). Determinants of gambling among male students in secondary schools in Imo State Nigeria. Journal of Substance Use, 24(2), 199205. https://doi.org/10.1080/14659891.2018.1535006.

\section{Article Google Scholar}


7. Aguocha, C.M., \& George, S. (2020). An overview of gambling in Nigeria. BJPsych International, pp.1-3. https://doi.org/https://doi.org/10.1192/bji.2020.28

8. Ajomale, G. (2017). Bad Money Habits The rise of the gambling culture in Nigeria. (Online) Available at: https://www.pulse.ng/lifestyle/money/bad-money-habits-therise-of-the-gambling-culture-in-nigeria/ce8j4yk

9. Awaworyi Churchill, S., \& Farrell, L. (2020). Australia's gambling epidemic: The role of neighbourhood ethnic diversity. Journal of Gambling Studies, 36(1), 97-118. https://doi.org/10.1007/s10899019-09865-W.

\section{Article PubMed Google Scholar}

10.Awo, A. (2015). Nigerian youths and sport betting. The Nation. (Online) Retrieved from: https://thenationonlineng.net/category/news

11. Bankole, E. T. (2019). Patterns and prevalence of gambling behaviour among youths in south-west Nigeria: a case study of youths in oyo and Ekiti State. British Journal of Psychology Research, 7(2), 22-46.

\section{Google Scholar}

12. BBC News. (2019). Gamblers Like Me: The Dark Side of Sports Betting -BBC Africa Eye documentary. (Online) Available at: https://youtu.be/JXgLwphEDMo

13. Binde, P. (2013). Why people gamble: A model with five motivational dimensions. International Gambling Studies, 13(1), 8197. https://doi.org/10.1080/14459795.2012.712150.

\section{Article Google Scholar}

14. Burgess, R. G. (1984). In the field: An introduction to field research. London: Allen and Unwin.

\section{Google Scholar}

15. Chambers, R. A., \& Potenza, M. N. (2003). Neurodevelopment, impulsivity, and adolescent gambling. Journal of Gambling Studies, 19(1), 53-84. https://doi.org/10.1023/A:1021275130071. 


\section{Article PubMed Google Scholar}

16. Chidozie, I. G., \& Ekechukwu, R. O. (2019). Joint influence of psychodemographic variables on adolescents' gambling behaviour in Rivers state, Nigeria. European Journal of Social Sciences Studies, 4(4), 259-269. https://doi.org/10.5281/zenodo.3529774.

\section{Article Google Scholar}

17. Chisholm, L., \& du Bois-Reymond, M. (1993). Youth transitions, gender and social change. Sociology, 27(2), 259279. https://doi.org/10.1177/0038038593027002006.

\section{Article Google Scholar}

18. Laws of the federation of Nigeria 1990, (1916). (Online) Available at: https://www.wipo.int/wipolex/en/text.jsp?file $\mathrm{id}=179687$

19. Du Bois-Reymond, M. (1998). 'I don't want to commit myself yet': young people's life concepts. Journal of Youth Studies, 1(1), 6379. https://doi.org/10.1080/13676261.1998.10592995.

\section{Article Google Scholar}

20. Duffy, K., Ferguson, C., \& Watson, H. (2004). Data collecting in grounded theory-some practical issues. Nurse Researcher, 11(4), 6778. https://doi.org/10.7748/nr2004.07.11.4.67.c6216.

\section{Article PubMed Google Scholar}

21. Farhat, L. C., Wampler, J., Steinberg, M. A., Krishnan-Sarin, S., Hoff, R. A., \& Potenza, M. N. (2020). Excitement-seeking gambling in adolescents: Health correlates and gambling-related attitudes and behaviours. Journal of Gambling

Studies. https://doi.org/10.1007/s10899-020-09960-3.

\section{Article PubMed Google Scholar}

22. Federal ministry of youth and sports development. (2019). Enhancing youth development and participation in the context of sustainable development. (Online) Available at: https://ndlink.org/wp-content/uploads/2019/06/National-YothPolicy-2019-2023-Nigeria.pdf 
23. Harnett, R., Thom, B., Herring, R., \& Kelly, M. (2000). Alcohol in transition: Towards a model of young men's drinking styles. Journal of Youth Studies, 3(1), 6177. https://doi.org/10.1080/136762600113040.

\section{Article Google Scholar}

24. Hing, N., Russell, A. M. T., Lamont, M., \& Vitartas, P. (2017). Bet anywhere, anytime: An analysis of internet sports bettors' responses to gambling promotions during sports broadcasts by problem gambling severity. Journal of Gambling Studies, 33(4), 1051-1065. https://doi.org/10.1007/s10899-017-9671-9.

\section{Article PubMed Google Scholar}

25. Meyer, G., Hayer, T., \& Griffiths, M. (2009). Problem gambling in Europe. In M. Griffiths, T. Hayer, \& G. Meyer (Eds.), Problem gambling in Europe. New York: Springer.

\section{Google Scholar}

26. Molinaro, S., Canale, N., Vieno, A., Lenzi, M., Siciliano, V., Gori, M., et al. (2014). Country- and individual-level determinants of probable problematic gambling in adolescence: A multi-level crossnational comparison. Addiction, 109(12), 20892097. https://doi.org/10.1111/add.12719.

\section{Article PubMed Google Scholar}

27.Mortimer, J. T., \& Larson, R. W. (2002). The changing adolescent experience. The Changing Adolescent Experience. https://doi.org/10.1017/cbog780511613913.

\section{Article Google Scholar}

28. Mustapha, R.A., Akande, R., and JImoh, S. (2017). Impact of poverty reduction program of the Kwara State government of Nigeria on the beneficiaries. International Journal of Economics, Commerce and Management, V(3), pp.247-262. https://ijecm.co.uk/wpcontent/uploads/2017/03/5318.pdf

29. Mustapha, S. A., \& Enilolobo, O. S. (2019). Effects of gambling on the welfare of Nigerian Youths: A Case Study of Lagos 
State. Journal of Gambling Issues, 43(December), 2944. https://doi.org/10.4309/jgi.2019.43.3.

\section{Article Google Scholar}

30. NOIPolls. (2017). New poll reveals rising trend of gambling in Nigeria. (Online) Available at: https://noi-polls.com/new-pollreveals-rising-trend-of-gambling-in-nigeria/

31. Nweze, T., Agu, E., \& Lange, F. (2020). Risky decision making and cognitive flexibility among online sports bettors in

Nigeria. International Journal of

Psychology. https://doi.org/10.1002/ijop.12663.

\section{Article PubMed Google Scholar}

32. Okafor, I. P. (2019). Causes and consequences of drug abuse among youth in Kwara state, Nigeria. Canadian Journal of Family and Youth / Le Journal Canadien de Famille et de La Jeunesse, 12(1), 147-162. https://doi.org/10.29173/cjfy29495.

\section{Article Google Scholar}

33. Omanchi, S. A., \& Okpamen, K. O. (2018). The changing patterns of gambling in Benue State: The case of emerging role of ICT (Information and Communications Technology) in contemporary makurdi metropolis. AASCIT Communications, 5(2), 2936. https://doi.org/10.5901/mjss.2014.v5n27p1086.

34. Oyebisi, E. O., Alao, K. A., \& Popoola, B. I. (2012). Gambling behaviour of university students in South-Western Nigeria. IFE Psychologia: An International Journal, 20(1), 250-260.

\section{Google Scholar}

35. $\quad$ Peltzer, K., \& Pengpid, S. (2014). Gambling behaviour and psychosocial correlates among university students in 23 low, middle and emerging economy countries. Mediterranean Journal of Social Sciences, 5(27), 10861092. https://doi.org/10.5901/mjss.2014.v5n27p1086.

\section{Article Google Scholar}

36. Potenza, M. N., Fiellin, D. A., Heninger, G. R., Rousaville, B. J., \& Mazure, C. M. (2002). Gambling: An addictive behaviour with 
health and primary care implications. Journal of Internal Medicine, 17(9), 721-732.

\section{Google Scholar}

37.Price Waterhouse Coopers. (2013). Gambling outlook: 2013-2017 (South Africa - Nigeria - Kenya) (Vol.

2). https://www.pwc.co.za/en/assets/pdf/gambling-outlook2013.pdf.

38. Reith, G. (2006). Research on the social impacts of gambling: Final report. Scottish Executive Social Research, pp.1-116.

39. Shanthi, A., Wah, L. K., \& Lajium, D. (2015). Discourse analysis as a qualitative approach to study information sharing practice in Malaysian board forums. International Journal on E-Learning Practices, 2, 159-169.

\section{Google Scholar}

40. Shehu, A. Y. (2004). Should gambling be a predicate for money laundering? Journal of Money Laundering Control, 7(3), 254-256.

\section{Article Google Scholar}

41. United Nations Office on Drugs and Crime (UNODC). (2018). Drug Use in Nigeria.

61. https://www.unodc.org/documents/nigeria//Drug Use Survey Nigeria 2019 BOOK.pdf

42. Vigna-Taglianti, F., Brambilla, R., Priotto, B., Angelino, R., Cuomo, G., \& Diecidue, R. (2017). Problematic internet use among high school students: Prevalence, associated factors and gender differences. Psychiatry Research, 257, 163171. https://doi.org/10.1016/j.psychres.2017.07.039.

\section{Article PubMed Google Scholar}

43. Woodman, D. (2009). The mysterious case of the pervasive choice biography: Ulrich Beck, structure/agency, and the middling state of theory in the sociology of youth. Journal of Youth Studies, 12(3), 243256. https://doi.org/10.1080/13676260902807227.

\section{Article Google Scholar}




\section{Author information}

\section{Affiliations}

1. Department of Sociology, Landmark University, Omu-Aran, Kwara State, Nigeria

Tunde Adebisi, Ogadimma Arisukwu \& Festus Asamu

2. Department of Sociology, University of Johannesburg, Auckland Park, South Africa

Oluwatobi Alabi

\section{Corresponding author}

Correspondence to Tunde Adebisi.

\section{Additional information}

\section{Publisher's Note}

Springer Nature remains neutral with regard to jurisdictional claims in published maps and institutional affiliations.

\section{Rights and permissions}

\section{$\underline{\text { Reprints and Permissions }}$}

\section{About this article}

\section{Cite this article}

Adebisi, T., Alabi, O., Arisukwu, O. et al. Gambling in Transition: Assessing Youth Narratives of Gambling in Nigeria. J Gambl Stud (2020).

https://doi.org/10.1007/s10899-020-09982-x

\section{Download citation}

- Accepted22 September 2020

- Published29 September 2020

- DOlhttps://doi.org/10.1007/s10899-020-09982-x Keywords

\section{- Gambling}

- Youth

- Problematic gambling 
- Discreet gambling

- Safe gambling

- Experimental gambling 